\title{
Scientific Racism on Display: Representations of Indigenous Cultures and Societies at the Turn of the Twentieth Century
}

\author{
Christina Williamson
}

\begin{abstract}
Through the analysis of photographs and newspapers, I analyze specific representations of indigenous people and cultures in the public arena, such as in museums and World's Fairs. Using and modifying Edward Said's model of Orientalism, I argue that these representations reinforced problematic and damaging ideas about aboriginal people.
\end{abstract}

Representations of Indigenous people in the late nineteenth and early twentieth centuries were beginning to take a form more familiar to us. The theory of Orientalism by Edward Said is a useful framework for studying and understanding how representations can perpetuate problematic and dangerous conceptions of others. By using the theory of Orientalism, I will examine racist representations of Indigenous people from across North and Central America created by anthropologists, photographers, and museums in the United States of America. Through the examination of photographs, newspapers and books, I will demonstrate some instances where these mediums have created a representation of Indigenous people that deny the agency of Indigenous people and create them in the image of a creature that is so obviously different from the "self."

To situate my analysis of representations of Indigenous people, I will briefly discuss Edward Said's two works Orientalism and Culture and Imperialism. Said explains that Orientalism is a type of knowledge formation that enables Westerners to define themselves in opposition to "Orientals." He notes that this is a crucial concept because it means that Westerners define themselves in opposition to the East: Westerners are everything that Easterners are not. Westerners can formulate oppositional identity to the East through the systematic acquisition of items (artifacts, bones) and literary knowledge (travel accounts etc.). ${ }^{2}$ The dissemination of Orientalist concepts is used to enforce the hegemonic dominance of the West over the Orient. Museums are one tool for the dissemination of this particular knowledge as exhibit creators perpetuate certain ideas of the "Other." I will shift Said's argument about Orientalism to consider Indigenous people in the Americas. I will show examples of Western dominance in the creation of certain representations of Indigenous people. It is significant to note that Indigenous people sometimes used these representations for their own advantage.

Said's work Culture and Imperialism also provides a framework for the sources that I used for my examination. His theories on Imperialism are translatable to the context of the Americas. The American expansion into the "Wild West" and Mexican territory is important to consider when examining American representations of Indigenous people because it plays a crucial role in justification of colonization of Indigenous territories. The Western and Mexican frontiers are lines between Euro-Americans and the Other which fit into Said's model. However, using the model only this way neglects the First Nations groups already grappling with American expansionism. I

\footnotetext{
${ }^{1}$ Edward Said, Orientalism (Toronto: Vintage Books a division of Random House ltd, 1994), first published 1978 by Pantheon Books a division of Random House ltd, 236-7.

${ }^{2}$ Ibid., 165.
} 
will consider Indigenous groups who had already faced colonization as well as those beginning to deal with its direct consequences from the 1850s onwards.

Said demonstrates that ethnography, linguistics, racial theory, and historical classification all codify difference. This ultimately leads to "evolutionary schemes going from primitive to subject races, and finally to superior or civilized peoples." 3 Said acknowledges that all cultures make representations of other cultures to better master them. However, few cultures actually succeed in mastering and controlling other cultures. According to Said, "it requires the study of Western knowledge or representations of the non-European world to be a study of both those representations and the political power they express." I plan to follow this methodology to better understand how science, anthropology and museums all institutionalize representations of Indigenous people that led to racism and dangerous stereotypes.

Four scholars in particular shaped my research. H. Glenn Penny is the author of Objects of Culture: Ethnology and Ethnographic Museums in Imperial Germany. Penny's text was useful in seeing the interconnections between German ethnologists and American anthropologists, such as the influence of Karl Weule on the creation of didactic displays in museums, a concept that Franz Boas brought to the American Museum of Natural History in the United-States. ${ }^{5}$ Penny also examines how audiences shape museums. The exhibit creators must please different groups of people including patrons, the government, scientists, and the public. ${ }^{6}$ Ruth B. Phillips, the author of Trading Identities, examines the role of tourist art in Indigenous/Euro-American economic relations and questions the consensus of tourist art as "inauthentic." Phillips argues that certain characteristics of Aboriginal crafts were identified by Whites as "Indian" and Aboriginal makers had to reimagine themselves in terms of the "conventions of Indianness" current among the consumer group purchasing their wares. ${ }^{8}$ Aboriginal people had to learn to adopt, mediate and engage with Western culture; Western culture similarly engaged with Aboriginal culture, although in an asymmetrical relationship. Last of all, Nancy Parezo and Don Fowler, the authors of Anthropology Goes to the Fair, present important examples of Indigenous agency and emphasize the role of science in racist concepts. Practiced in the basement of one of the exhibition buildings at the Louisiana Purchase Exposition, craniometry and anthropometry solidified racist concepts because of the belief that the differences in skulls were representative of inferiority or superiority of an entire race. ${ }^{9}$

I used a variety of primary sources for my research including newspapers, photographs and books. Newspapers are useful sources because they are often representative of a popular perspective and they inform large audiences and therefore have a great impact. Newspapers also have their limitations because they are quickly printed and disposed, information can be sensationalized or outright false, and quotes within the stories can be taken out of context. Photographs are also a useful source, particularly because of my focus on museum exhibits. Exhibits are rarely described in

\footnotetext{
${ }^{3}$ Edward, Said, Culture and Imperialism (Toronto: Vintage Books a division of Random House ltd., 1994), first published in 1993 by Alfred A. Knopf, Inc., 108.

${ }^{4}$ Ibid., 100.

${ }^{5}$ H. Glenn Penny, Objects of Culture: Ethnology and Ethnographic Museums in Imperial Germany (Chapel Hill: University of North Carolina Press, 2002), 150.

${ }^{6}$ Ibid., 132.

${ }^{7}$ Ruth B. Phillips, Trading Identities: The Souvenir in Native American Art from the Northeast 1700-1900 (Montreal \& Kingston: McGill-Queen's University Press, 1998), x.

${ }^{8}$ Ibid., 9.

${ }_{9}^{9}$ Nancy J. Parezo and Don D. Fowler Anthropology goes to the Fair: The 1904 Louisiana Purchase Exposition (Lincoln: University of Nebraska Press, 2007).
} 
detail and photographs are often the only way that I can "see" what they looked like. This allows me to study the exhibit like a text; the placement of items in relation to each other is very telling in museum exhibits. There are also limitations to photographs. John Berger in Ways of Seeing shows that:

...photographs are not, as is often assumed, a mechanical record...the photographer's way of seeing is reflected in his choice of subject. Yet although every image embodies a way of seeing, our perception or appreciation of an image depends also on our way of seeing. ${ }^{10}$

When examining photographs the plurality of perspectives must be considered, including the perspective of the curator and anthropologist who developed the display, the photographer who chose that specific subject and focus, and my own interpretations of the subject in the photo based on Said's framework of Imperialism and Orientalism.

Museums are often traced back to cabinets of curiosities kept by Victorians in their homes. ${ }^{11}$ The 'curiosities' collected in the seventeenth and eighteenth centuries carry the signification of wonderment. ${ }^{12}$ Penny argues that although Stephen Greenblatt's theory of wonder describes the initial reaction of Europeans at Contact, it can include the "first encounters with radical difference that took place centuries later...in museums." "Greenblatt argues that the idea of the "marvelous" was a way for Europeans to use conventional intellectual structures to mediate with other cultures. ${ }^{14}$ Through the rhetoric of wonder and marvel, Greenblatt argues Europeans were therefore able to possess what was foreign and unknown and appropriate these marvels through representations of them. ${ }^{15}$ The shift from the term 'curiosities' to artifacts and specimens demonstrates a paradigmatic change. Instead of curios randomly placed in a display case, specimens derived their meaning from the placement in relation to other objects. ${ }^{16}$ For example, the image below of an Aztec ceramic collection is from an earlier museum display; there is minimal labeling of the items and they are organized in a particular manner. The pots are with other pots from the same material culture. This shows the view of the period that emphasized the classification of items to make sense of one item compared to others like it. In contrast, a curio cabinet is an eclectic mix of items that pleased or interested the owner, regardless of the cultural or regional specifics. This is the greatest difference between a curio cabinet and an early museum display. The earliest museum displays included almost every piece owned by a museum. This was viewed as more scientific because it allowed the viewer to analyze and compare the different versions of the same object in order to draw their own conclusions based on the artifacts and very limited interpretation by the anthropologist. ${ }^{17}$

\footnotetext{
${ }^{10}$ John Berger, Ways of Seeing, (Toronto: Penguin Books, 2008), first published in Great Britain by the BBC and Penguin Books Ltd., 1972, 10.

${ }^{11}$ Even Maurer "Presenting the American Indian" in The Changing Presentation of the American Indian. Seattle: University of Washington Press, 2000.

12 Phillips, Trading Identities, 6

${ }^{13}$ Penny, Objects of culture, 207.

${ }^{14}$ Stephen Greenblatt, Marvelous Possessions: The Wonder of the New World (Chicago: The University of Chicago Press, 1991), 53-4.

${ }^{15}$ Ibid., 8, 14-15.

${ }^{16}$ Penny, Objects of Culture, 167.

17 Ibid., 147.
} 


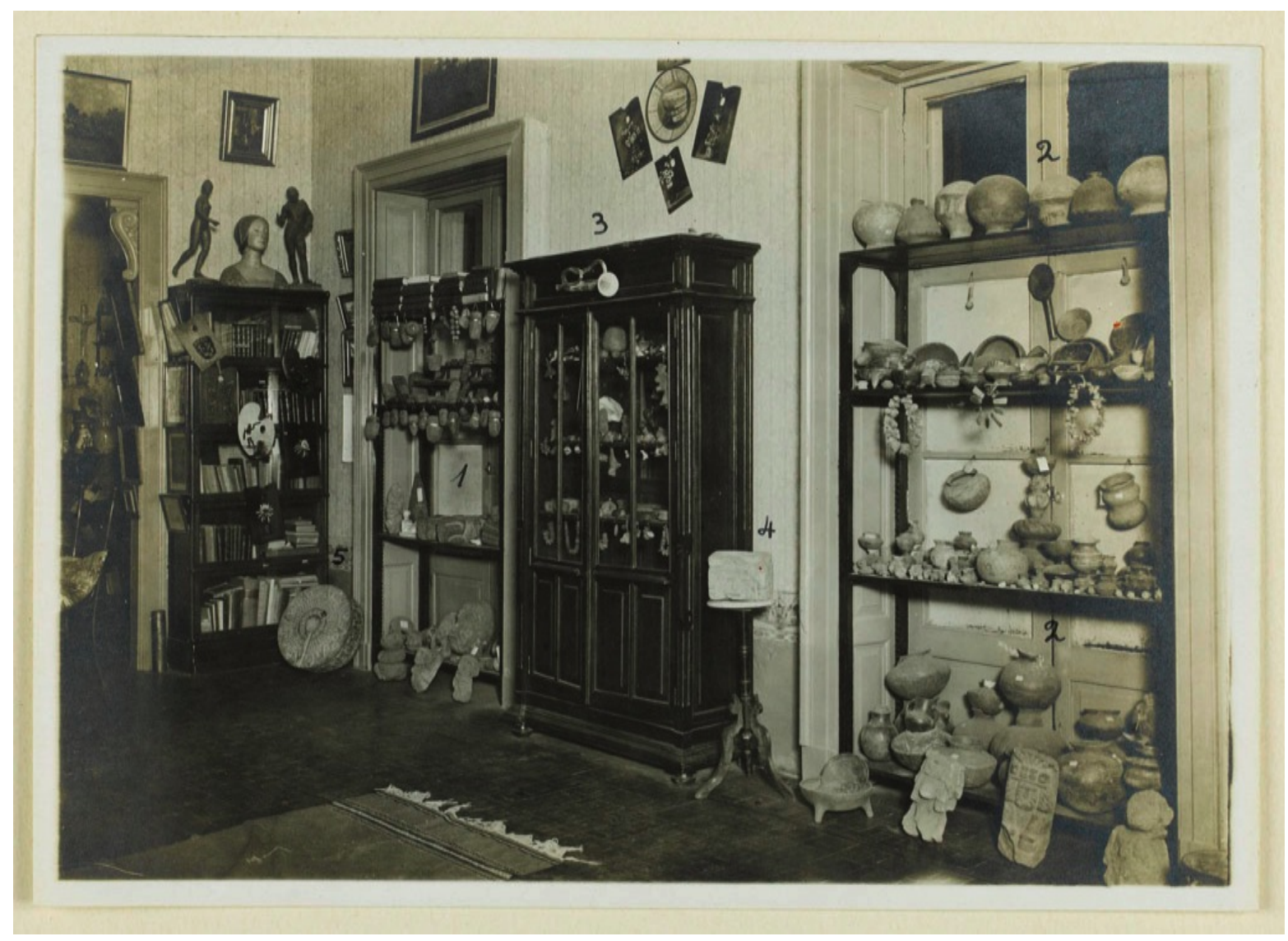

Ceramic Collection Lithic Collection n.d. ${ }^{18}$

Penny argues that a grand narrative of museums progressing from antiquarian interests and wonderment to the enlightened times of science is a trap and that caution is necessary when contextualizing any analysis of museums. ${ }^{19}$ The whiggish narrative describes museums coming out of a dark age of chaos and disorder into a scientific realm of order through classification. ${ }^{20}$ John Mackenzie, a critic of Said, notes that curiosities seemed unknowable, but once placed in a display case they were potentially knowable. Mackenzie links this to the Romantic era and the belief that by increasing one's knowledge of the world and God's design, a person could become closer to God. ${ }^{21}$ Mackenzie also suggests that the industrial age affected the growth of museums that we see in the mid-nineteenth century because of the general sense of progress. The construction of telegraph lines and railroads across the United States and the digging required for their installation led to the discoveries of large quantities of objects and human remains. ${ }^{22}$ This ties American expansionism to the acquisition of artifacts, bodies and the so-called science that lay behind it.

\footnotetext{
${ }^{18}$ Ceramic Collection Lithic Collection, n.d., BAE 4523 00836400, National Anthropological Archives, Smithsonian Institution.

${ }^{19}$ Ibid., 165.

${ }^{20}$ The whiggish conception of history is a liberal view that emphasizes the idea of history as a great march of progress. Ibid., 168.

${ }^{21}$ John M. Mackenzie, Museums and Empire: Natural History, Human Cultures, and Colonial Identities (Manchester: Manchester University Press, 2009), 1.

${ }^{22}$ Ibid., 3.
} 
Didactic museum displays created a polarization between Europeans and Americans of European descent and Indigenous people despite the intentions of the ethnologists. ${ }^{23}$ Mackenzie acknowledges that museums in imperial territories represented a Western view of the world, but museums "offered more than an arrogant culture othering of nature and peoples: it also, ultimately, if not immediately, stimulated fresh forms of respect." ${ }^{24}$ Still, Mackenzie concedes that no invitation or openness was extended to Aboriginal people to participate in the creation of exhibits and define their own representation and Aboriginals were instead treated more as part of the landscape than as people. $^{25}$

The Age of Romanticism, loosely encompassing the nineteenth century, was a reaction to the era of rationalism brought on by the Enlightenment. This period brought on a different perspective of Aboriginal people. Said argues that in the context of Orientalism, romantics believed that the Orient had the power to re-energize the Occident. That is to say, romantics believed the Orient could defeat the materialism and mechanization of the West. ${ }^{26}$ This conceptualization of the Other as less modern, more natural, and more exotic is clearly used in the context of Aboriginal people in America as well. Historian Benjamin Keen explains that Europeans and Americans viewed Aboriginal people in a more positive light in this period. ${ }^{27}$ Of all Indigenous groups, Keen explains the Aztecs were of greatest interest: "The exoticism of Aztec civilization, its ambiguous blend of refinement and barbarism" appealed to the romantics who also "admired Aztec bravery, stoicism, and eloquence." ${ }^{28}$ A 1922 article in the New York Times featuring the Museum of the American Indian exemplifies this perspective. ${ }^{29}$ The article, entitled "Romantic Life of American Indian Shown in New Museum Exhibit,"” used the romantic perspective. The introduction began with:

Lovers of romances as well as students of antiquity will find colorful material for story and essay in the ...Museum of the American Indian. Here, amid carvings and household gods of peoples long lost to the world, riches of almost unimagined splendor are gathered into cases of glass... ${ }^{30}$

The journalist focused on how these artifacts became objects for White Americans, allowing them to create their own dramas about the "lost" Aztecs. The imagery of splendor conjures ideas of exotic ancient people whose great civilization has ended. This is a characteristic Romantic representation. This article did not allow Indigenous people to create an image of themselves; after all, they were long 'lost' to the shadows of the jungle. Instead, it was the duty of 'lovers of romance and students of antiquity." 31 The removal of Indigenous people's agency in creating their own representation is an important feature of Imperialist and Orientalist notions. Solely the dominant group has agency to create representations of the Other. The Other may choose to comply with that representation or figuratively vanish altogether. The article stated that the museum had a

\footnotetext{
${ }^{23}$ Penny, Objects of Culture, 14.

${ }^{24}$ MacKenzie, Museums and Empire, 4-5.

${ }^{25}$ MacKenzie, Museum and Empire, 25.

${ }^{26}$ Said, Orientalism, 115.

${ }^{27}$ Benjamin Keen, The Aztec Image in Western Thought (New Brunswick, NJ: Rutgers University Press, 1990$), 310$.

${ }^{28}$ Ibid., 310.

${ }^{29}$ The American Museum of the Indian was opened by a wealthy New York businessman, George Heye and was later absorbed into the Smithsonian Institution which opened a new museum in New York in 1994 and in Washington D.C. in 2004.

30 "Romantic Life of American Indian Shown in New Museum Exhibit," New York Times, November 12, 1922.

${ }^{31}$ Ibid.
} 
"...minute catalogue of the collection and the arrangement by tribes and years of value in the study of obscure points in the development and decline of Indian life in North and South America" (emphasis added). ${ }^{32}$ This quote demonstrated the presumption that contemporary Indians and Aztecs were not like the ones of earlier time: that they were in decline and would soon vanish completely. "Romantic life of American Indians Shown in New Museum Exhibit" also showed an interesting connection between the Romantic and the Enlightenment ages. The article described dioramas in the museums: "There [was] a village in miniature...showing diminutive squaws busily engaged in the job of housekeeping." "33 This anachronism placed bourgeois women's gender role on Aboriginal women, tying to Rousseau's conceptualizations of domestic women. Rousseau described his version of the State of Nature as:

The first developments of the heart were the effect of a new situation that united the husbands and wives, fathers and children in one common habitation. The habit of living together gave rise to the sweetest sentiments know to men: conjugal love and paternal love. Each family became a little society all the better united because mutual attachment and liberty were its only bonds; and it was then that the first difference was established in the lifestyle of the two sexes, which until then had had only one. Women became more sedentary and grew accustomed to watch over the hut and the children, while the man went to seek out their common subsistence. ${ }^{34}$

People connected Rousseau's idea of the State of Nature to Aboriginal people who they saw as relics. Europeans and Euro-Americans had supposedly long-since surpassed this evolutionary state in their progressive culture. Romantic nostalgia for the State of Nature included the longing for what they saw as more innocent times of pre-industrialized society, when life was simpler, happier, and more natural. Museums exhibited this sort of State of Nature by creating dioramas of Aboriginal people in their "natural habitat." The image below was an example of a diorama with mannequins posed to demonstrate their "natural surroundings," which included a Western-styled nuclear family shown in the display. Euro-centric assumptions such as this display led to the belief in the inferiority of Indigenous people because the family unit was not necessarily set up in the same way as Europeans and Americans. Westerners viewed Aboriginal peoples as prone to lechery and promiscuity. Rather than viewing their cultures as different, Aboriginal cultures were instead viewed as wrong. Paradoxically, Indigenous people were praised because of their perceived childlike nature, living in the State of Nature.

\footnotetext{
${ }^{32}$ Ibid.

${ }^{33}$ Ibid.

${ }^{34}$ Jean-Jacques Rousseau, trans. Donald A. Cress, in "Discourse on the Origins and Foundations of Inequality Among Men," in Jean-Jacques Rousseau: The Basic Political Writings (Hackett Publishing Company, 1987), 63.
} 


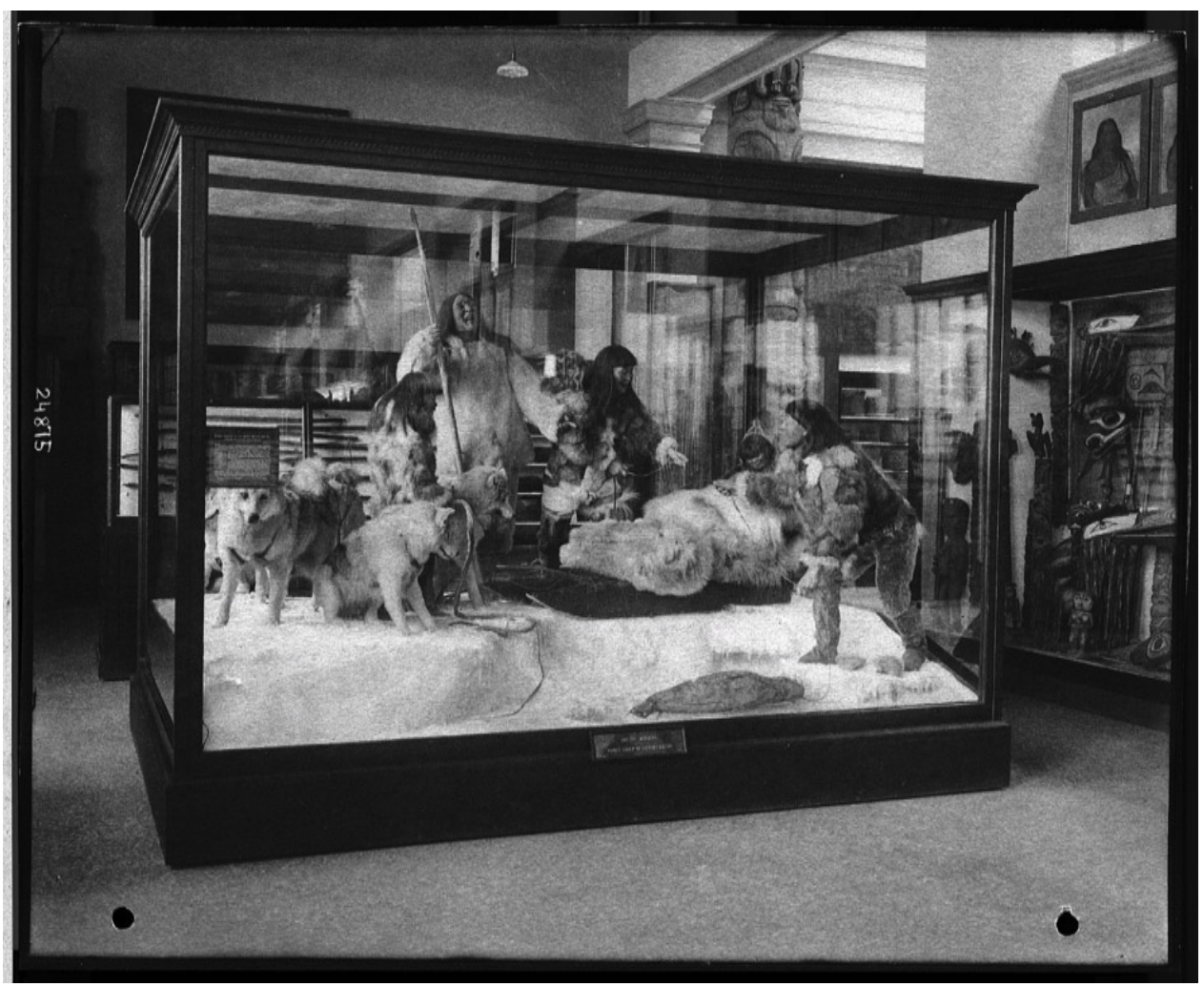

Arctic Region Life Group, Anthropology Exhibit, U.S. National Museum, c. 1915. ${ }^{35}$

Hierarchical conceptions of Indigenous people as close to nature revealed a Western desire to return to the State of Nature. Not only was there the belief in the intrinsic superiority of whites over Indigenous people, but also the belief that the contemporary Indigenous people were inferior to those of the past. An article from the New York Times in 1902 included an interview with physical anthropologist, Aleš Hrdličk. Upon returning from an expedition in Mexico, he explained that there remained a large number of "pure" Aztecs. Hrdlička explained that:

Among scientists the fact that some of the Aztecs still survive is well known. It is not generally known, however, in what localities the purest types may be found. There remains but a small remnant of the large and notable population of Aztec Indians which the Spanish explorers found in Mexico. As to the culture the Aztecs to-day are on a very much lower level than were those encountered by Cortez. History has told us how the artisans of the early days were subjugated by the invaders and put to work as common laborers. Also, how the priests, in their efforts to wipe out the religion of the aborigines, destroyed all of their works of art, which were so closely related with their religion...Then came the introduction of rum...That alone would be almost sufficient to ruin a noble race. To me it is not

\footnotetext{
35 Arctic Region Life Group, Anthropology Exhibit, U.S. National Museum, c. 1915, 2002-10659, Historic Images of the Smithsonian, Smithsonian Archives (SIRIS), Washington D.C.
} 
strange that the wonderful people of a few centuries ago have degenerated into the people I found in a few scattered localities in the country. ${ }^{36}$

Hrdlička confirmed the idea that Indigenous people were in decline due to the Spaniards. ${ }^{37}$ Baron Alexander Von Humboldt, a highly influential writer/scholar, influenced many anthropologists and his conceptualization of the Aztecs certainly influenced Hrdlička. Humboldt emphasized that people existed in stages, progressing from savagery to barbarism and finally to civilization. He also believed that the environment affected people to the extent that barbarians could regress back into savagery. Humboldt explained that the "Tartars" who came from Asia traveled to the Americas where they "relapsed into barbarism under the influence of a climate less favorable to...individuals." ${ }^{38}$ Humboldt was discussing the regression of Tartars thousands of years ago and it is a significant statement, meaning people can regress at any point in history. Though Humboldt wrote his book nearly a century before, Hrdlička enunciated a similar theory: the conquistadors caused the regression of the great Aztec civilization into the "ruin" found 1902. Hrdlička also decried the destruction of Aztec culture by Cortes and other conquistadors as he viewed cultures as bubbles that should remain pure and untouched. This was a problematic view of cultures because it denied any possibility for the change and development. Cultures influence each other. This cultural grey area makes the concept of 'authenticity' extremely difficult if not impossible to define.

The idea of 'authentic Indianness' was a salient feature of this period. Paige Sylvia Raibmon explains that the authentic Indian was a white imagining of the definition of Indianness. ${ }^{39}$ She argues that Aboriginal people engaged in this imagining, but it was not a real choice. They had to use the framework of authenticity because that was the only way to engage with colonial powers, forcing them into the category of Other. ${ }^{40}$ Resulting from the ideas of authenticity was salvage anthropology: anthropologists among others raced to save all that was "authentic" before all the Indians vanished. ${ }^{41}$ Edward Sheriff Curtis was a photographer who spent a large portion of his life documenting the "Vanishing Races" in North America. Between 1907 and 1930, Curtis photographed tribes across Canada and the United States, finally creating a twenty-volume work with twenty accompanying portfolios of photographs. ${ }^{42}$ Curtis felt an urgency to record the Aboriginal people before they vanished. ${ }^{43}$ Curtis purportedly wanted to capture the "authentic Indian." In his mind, this meant taking staged photographs. If their clothes did not conform to his preconceived notions of authenticity, Curtis provided his subjects with "authentic" ones. His images did not give the viewer a great idea of how various Indigenous groups lived in the early nineteenth century, but they provided an excellent window into how Curtis imagined the way

\footnotetext{
36 "Curiosities brought here from Mexico," New York Times, August 24, 1902.

${ }^{37}$ A concept that we can link to the Black Legend and Bartolome de Las Casas

${ }^{38}$ Alexander von Humboldt, Researches concerning the institutions \& monuments of the ancient inhabitants of America (London, 1814) 1:156, accessed 16 April 2010, http://galenet.galegroup.com/servlet/ Sabin?af $=$ RN\&ae $=$ CY105088918\&srchtp $=$ a\&ste $=14$

${ }^{39}$ Paige Raibmon, Authentic Indians: Episodes of Encounter from the Late Nineteenth-Century Northwest Coast (Duke University Press: Durham, 2005), 3.

${ }^{40}$ Ibid., 10.

${ }^{41}$ Ibid., 5 .

${ }^{42}$ Mick Gidley, ed., Edward S. Curtis and the North American Indian Project in the Field (Lincoln: University of Nebraska Press, 2003), 1.

${ }^{43}$ Ibid., 13.
} 
Indigenous people lived. Curtis ventriloquized the voice of his Aboriginal subjects. ${ }^{44}$ The subjects were often paid or willing to have their photo taken. They chose to allow Curtis to come to their camp, wear the costumes he provided and they "played Indian." Although an asymmetrical power relationship, the Aboriginal groups who came into contact with Curtis did have a choice to ignore him or cooperate, and they worked within the confines of their given roles as a vanishing, authentic people. Curtis would go so far as to ensure that the background of the photograph was particularly picturesque and would ask his subjects to reconstruct scenes from the 'past' such as war parties and preparations for ambushes. ${ }^{45}$ Curtis said:

I made one resolve, that the pictures should be made according to the best modern methods and of a size that the face might be studied as the Indian's own flesh. And above all, none of these pictures would admit anything which betokened civilization, whether in an article of dress or landscapes or objects on the ground. These pictures were to be transcriptions for future generations that they might behold the Indian as nearly lifelike as possible as he moved about before he ever saw the paleface or knew that there was anything human or in nature other than what he himself had seen.

It is clear Curtis believed the Indigenous people were disappearing. Anxious his subjects adherence to authenticity 'standards,' he described in the article how he ensured they "played Indian" correctly. This was a created authenticity, however, fashioned by Curtis himself. To Curtis, the authentic Indian only existed in the pre-contact world; technology was directly to blame in their disappearance. The disappearing culture he tried to capture on film was a culture of his own imagination.

Another aspect of Curtis's work was the exoticization of his Aboriginal subjects. Mick Gidley, a professor of American Literature who has studied Curtis's works extensively, argues that Curtis tried to raise awareness of the vanishing Indians and "to do this, he often resorted to notion of the Indians as exotic, difficult to understand, and wild." 46 Exoticization is just a further othering of Indigenous people. Many books depict Curtis as a man trying to do a good thing--apparently well respected and loved by the tribes he visited. Yet, consistent with another prominent feature of Imperialism and Orientalism, Curtis was strongly paternalistic towards Aboriginal people, believing "... an Indian is like an animal or a little child. They instinctively know whether you like them-or if you are patronizing them." ${ }^{47}$ Apparently, the irony was lost on Curtis. To emphasize Curtis's representations of Aboriginal people, I want to include a few of the captions and images that Curtis took for his massive twenty-volume work.

\footnotetext{
${ }^{44}$ Ibid., 29

${ }^{45}$ Ibid., 15 .

${ }^{46}$ Ibid., 28.

${ }^{47}$ Florence Curtis Graybill and Victor Boesen, Edward Sheriff Curtis: Visions of a Vanishing Race (New York: Thomas Y. Crowell Company, 1976), 13.
} 


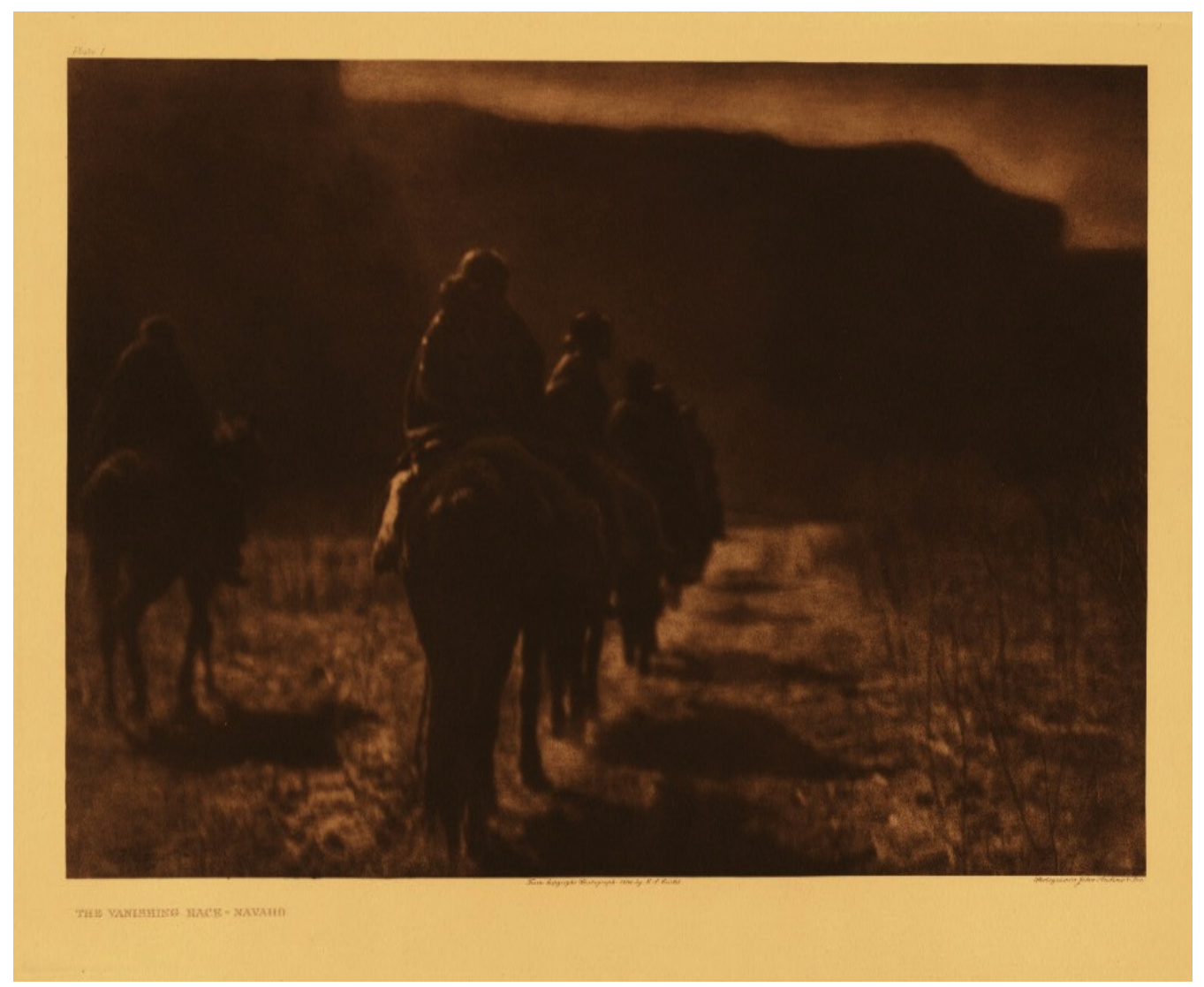

Edward S. Curtis, The Vanishing Race, 1904. ${ }^{48}$

The V anishing Race is very clear as to what it is trying to depict. The caption states:

The thought which this picture is meant to convey is that the Indians as a race, already shorn in their tribal strength and stripped of their primitive dress, are passing into the darkness of an unknown future. Feeling that the picture expresses so much of the thought that inspired the entire work, the author has chosen it as the first of the series. ${ }^{49}$

Right from the beginning of his work, Curtis stated his concern for the disappearance of the authentic Indian race. He had that romantic perspective and nostalgia for those old times when Aboriginal peoples were untouched and closer to nature. He even tied the strength of the tribe to their style of dress. Civilization literally stripped Aboriginal people of their previous greatness, much like Hrdlička's belief that the Aztecs and their great civilization were lost. However, the search for the lost purity of culture was not the only theme of Curtis' work. For example, he has an image of a young woman who he described as:

\footnotetext{
${ }^{48}$ Ibid.

${ }^{49}$ Edward S. Curtis, The Vanishing Race, http://hdl.loc.gov/loc.award/ iencurt.cp01001, 1904 accessed April 16, 2010
} 


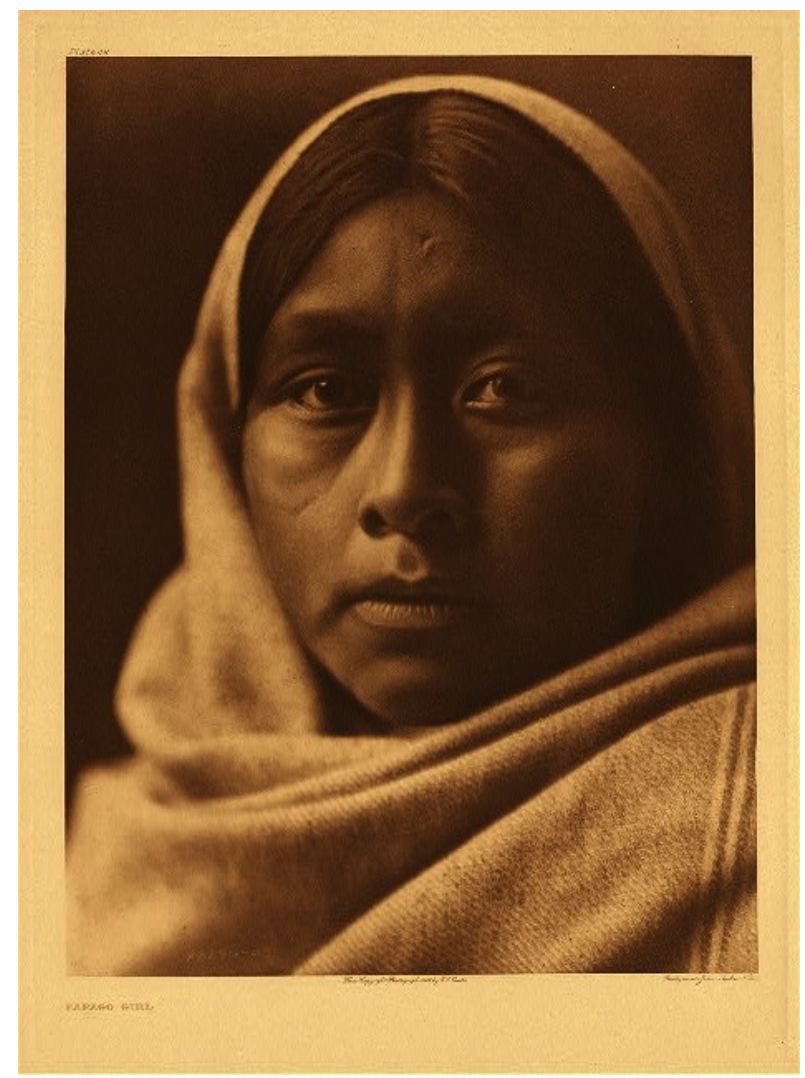

Edward S. Curtis, Papago Girl, 1907. ${ }^{50}$

A particularly fine-looking Papago girl of as nearly pure blood as can be found in the region. The northern Piman tribes have been in direct contact with Spanish people for more than two centuries. Much of the early foreign blood, however, has become so blended that its physical influence is no longer apparent. Indeed there are many instances in which the Indians insist that their blood is entirely Aboriginal, whereas in fact an infusion of alien blood is traceable several generations back. ${ }^{51}$

Curtis was fascinated by the idea of pure Indians. He believed in their superiority over people of mixed race or people who became more "civilized." They were pure and noble, unsullied by the bad Spanish blood or industrial society. He saw Aboriginal people as entrenched in the past and stagnant. The notion that, as with all cultures, Aboriginal cultures changed constantly before contact and continued to change after contact was completely missing from his work. Contrary to the assumptions made by so many anthropologists and others who studied Indigenous people, Aboriginal people did not have a stone-age culture fossilized since the ice age. This attitude connects to Said's argument that the Other is frozen and static in its difference from the West. ${ }^{52}$ Like many others, Curtis was interested in finding the pure Indians, unmixed with the blood of Spaniards.

\footnotetext{
${ }^{50}$ Curtis, The Papago Girl.

${ }^{51}$ Edward S. Curtis, The Papago Girl, 1907, http://hdl.loc.gov/loc.award/ iencurt.cp02009

${ }^{52}$ Said, Orientalism, accessed April 16, 2010, 20.
} 
Fredrick Starr, an anthropologist and curator of the geology and later ethnographical collections at the American Museum of Natural History, made a number of expeditions into Mexico. At the turn of the twentieth century, he described one of his attempts to find people of pure Maya blood. He explained that a priest heard pure Mayans had spots on their sacral area (lower back). At first, Starr was unable to find any spots on Aztec people, nor on any Mayans. He then began to examine infants and found that young ones had the spot. He explained that "it seem[ed]...to be far more evanescent among the Mayas than among the Japanese and other populations, being rarely found in individuals of more than ten months of age. ${ }^{\text {"53 }}$ Starr did not connect these 'Mongolian blue spots' to the people he saw in Japan. Instead, Starr declares that these marks demonstrate the purity of a Mayan person. Based on his sample of seven infants, Starr concluded that having the mark denoted purity of Mayan blood. ${ }^{54}$ To make his methodology more 'scientific,' Starr included sketches of the spots' various shapes and descriptions of their shape and colour. Starr also acknowledged that to refer to a person's wits (sacral spot) was incredibly insulting. This apparently did not stop Starr from measuring the seven babies and questioning the mothers of other children in the village about the uits of their older children. ${ }^{55}$ Starr's behaviour demonstrated the entitlement that he and other anthropologists felt towards Aboriginal people. As a white, wealthy, American man, he was in a position of greater power. He used those privileges to examine a very common birthmark, even though doing so was considered offensive. This entitlement to come into villages and measure people regardless of their sentiments was paternalistic and demonstrative of the Imperialistic attitude of Orientalist 'scientists' of the period.

John Mackenzie asserts that museums were the public face of scientific endeavor--a point of contact between scientists and visitors. ${ }^{56}$ Some 'scientific' aspects of museums were arguably not very scientific at all, as seen in Starr's work. Body-snatching, for example, was an aspect of museum collecting that was unscientific and unethical. There was an extensive trade in human remains. University departments and European colonial governments all collected physiologically exotic skeletons for their collections. ${ }^{57}$ Body-snatching "was stimulated by sciences that were deeply implicated in the racial theory of the day, [and] facilitated by the gruesome practices such as boiling the remains to secure the skeleton." ${ }^{58}$ Anthropologist Abigail Clouse shows that it was not only anthropologists who were collecting bodies, arguing military surgeons were often in a perfect position for body snatching. ${ }^{59}$ Not only were they participants in western expansion, but their position as surgeons meant they had a knowledge and interest in bodies in the first place. "Government scientists conceived of the west as an enormous, untamed national laboratory," Clouse explains. ${ }^{60}$ Clouse describes army surgeon Henry Crecy Yarrow who collected over 127 crania. Many simply stumbled over a skeleton, but others made a more concerted effort to obtain

\footnotetext{
${ }^{53}$ Fredrick Starr, "The Sacral Spot in Maya Indians," in Science 17, no. 428 (1903): 433.

${ }^{54}$ Ibid.

${ }^{55}$ Ibid., 432.

${ }^{56}$ MacKenzie, Museums and Empire, 1.

${ }^{57}$ Ibid., 10.

${ }^{58}$ Ibid., 10.

${ }^{59}$ Abigail Clouse, "The Social History of a National Collection: Anthropology, Repatriation and the Politics of Identity," (PhD diss., University of Arizona, 2006), 46.

${ }^{60}$ Ibid., 48.
} 
skeletons to send to museums. Yarrow belonged to the latter category. ${ }^{61}$ In one letter, Yarrow wrote:

I am glad to be able to tell you I have procured for the museum some 'Ute' crania among others that of Wah-Ker, the celebrated chief who instigated the war [18]65. The operation was attended with some little risk, as a band of Indians were living near the graves. Happily, nothing occurred to prevent our success. ${ }^{62}$

This letter shows his awareness that these bodies were not given under the auspices of the family. In fact, there was risk of fighting for these bodies between the army and the Ute. Yarrow also attempted to collect the bodies of known people to the government, such as famous chiefs, because these bodies were considered more interesting. MacKenzie notes that this was part of a process of "objectifying the bodies of 'others' in order to explain and justify... [racial] dominance." is the objectification of bodies an aspect of racial dominance, but it was a way of validating American expansion and the resulting disenfranchisement of Aboriginal people. Dehumanization of Indigenous peoples made it much easier to take Aboriginal land for settlement without guilt. Through the pseudo-sciences of anthropometry and craniometry, scientists 'proved' the racial inferiority of all non-whites.

In his book, Anthropometry, Hrdlička defined this 'science' as "the conventional art or system of measuring the human body and its parts." ${ }^{64} \mathrm{He}$ explained that anthropometry was used by medical and dental professionals, as well as by recruiting armies. More importantly, "certain measurements play[ed] important roles in criminological and medico-legal identification. Finally, measurements have become invaluable aids to scientific research in physiology, anatomy and especially anthropology." ${ }^{65}$ I use quotation marks around 'science' because anthropometry is far closer to what Karl Popper would describe as 'pseudoscience.' Popper explains that while science is predictive and verifiable, pseudoscientific theories have a veneer of explanatory power, using anecdotal situation as proof of its scientific merit. ${ }^{66}$ This definition fits anthropometry perfectly. It appeared scientific by coating itself in the veneer of precision, employing measurements and numbers as evidence. I am not discussing the objectivity of science, but rather how anthropometry was a method of perpetuating racism and confirming hierarchical conceptions of races.

Hrdlička was also an incredibly active collector of bodies. He was implicated in both the collecting of the body of Qisuk, the father of Minik, the New York Eskimo, as well as collecting the bodies of anyone that passed away while working at the Louisiana Purchase Exposition in 1904. Kenn Harper, a journalist who chronicled the life of Minik, described Hrdlička in a rather sinister light, describing him as a physical anthropologist who "relished" the chance to examine the bodies of four of the New York Eskimo. ${ }^{67}$ The Inuit from Greenland were brought down to New York by the

\footnotetext{
${ }^{61}$ Ibid., 53.

${ }^{62}$ Letter of John W. Powell from Yarrow, June 1 1883, quoted in Abigail Clouse, "The Social History of a National Collection: Anthropology, Repatriation and the Politics of Identity."

${ }^{63}$ Museums and Empire, 11.

${ }^{64}$ Hrdli ka, Aleš, Anthropometry (Philadelphia: The Wistar Institute of Anatomy and Biology, 1920$), 7$.

${ }^{65}$ Ibid., 7.

${ }^{66}$ Sir Karl Popper, Conjectures and Refutations: The Growth of Scientific Knowledge, (New York: Routledge \& Kegan Paul, 1963), reprinted in 2004, second edition, 45.

${ }^{67}$ Kenn Harper, Give Me My Father's Body: The Life and Times of Minik the New York Eskimo. (New York: Steerforth Press, 2000), first published in Canada in 1986 by Blacklead Press, 92.
} 
famous Arctic explorer Robert Peary, who often took the skulls and bodies of people who had died (many of whom he knew personally) down to New York. ${ }^{68}$ Franz Boas gave Peary the idea of bringing down Inuit, since he had studied them in the Canadian Arctic. However, even he was shocked when Peary brought six people to New York. Four of the six Inuit died, and the only surviving adult returned to Greenland while the Wallace family took in Minik. ${ }^{69}$ William Wallace had a bone-macerating factory on his land. The macerating factory removed flesh from bones and bleached them for the Smithsonian Institution. This macerating plant was where the bodies of the four dead Inuit were "cleaned off." "With a bag of sticks and rocks replacing Qisuk's body, a fake funeral was staged for Minik's benefit—a decision that was defended by Boas. ${ }^{71}$ Although Boas felt that this would be easiest for Minik, his paternalist perspective is another salient component of Orientalism. Gendering of the Self versus the Other is an interesting component to Said's theory, applicable to this situation. The Other is naturally female and needs the guidance and strong hand of the masculine West. ${ }^{72}$ The people of the American Museum of Natural History chose to stage a fake funeral, and believed that bleaching the bones of Minik's comrades at the home of Minik's adoptive father would be best for Minik. Minik then spent the rest of his life attempting and failing in his effort to have the bones of his father returned to him.

Hrdlička's connection to this story is his fifty-page analysis entitled "An Eskimo Brain." Published in 1901, Hrdlička named the owner of the brain as Kishu (Qisuk) in his article. Hrdlička also described Qisuk's death from tuberculosis, including photos of not only the brain, but also a frontal and profile photo of Quisuk and Minik naked. I have stated before that anthropometry was a pseudoscience that attempted to find physiolgical differences between races. Throughout this article, Hrdlička compared Qisuk's brain to the average Euro-American brain. What he finds is that there is little difference between Qisuk's brain and a white person's. Hrdlička wrote: "the proportions of the cerebrum and cerebellum to the whole brain [were] very nearly like those of whites, but the relative weight of the pons and the bulb [was] slightly greater., ${ }^{, 73}$ He noted that, in general, the brain of Qisuk was larger and heavier than the brains of Whites, ${ }^{74}$ concluding that the brain of Qisuk demonstrated his superiority to groups of other Eskimos. He wrote:

The morphological inferiority of the two male brains described by Chudzinski, and, on the other hand, the marked superiority of Kushu's [Qisuk]...brain, may be to some extent individual condition and represent more the extremes than the average of Eskimo brains. At the same time it is possible that [the two inferior Eskimo brains] belonged to some family of the great Eskmio tribe intellectually less developed than the Smith Sound group to which Kishu...belonged. The Smith Sound party which Lieutenant Peary brought to New York were by no means dull or incapable people. This is especially well demonstrated in Menee [Minik], the son

\footnotetext{
${ }^{68}$ Ibid., 69.

${ }^{69}$ Aleš Hrdli ka, "An Eskimo Brain," in American Antbropologist 3, no. 3 (1901): 454.

${ }^{70}$ Harper, My Father's Body, 59.

${ }^{71}$ Ibid., 88.

${ }^{72}$ Said, Orientalism, 182.

${ }^{73}$ Hrdli ka, "An Eskimo Brain," 454.

${ }^{74}$ Ibid., 490.
} 
of Kishu, who has not only shown a remarkable facility for adjusting himself in every way to civilized life, but has made very good progress in public school. ${ }^{75}$

Hrdlička's text displayed racialist overtones, stating that a person was determined by his physiological characteristics which connected him to a certain group. The Smith Sound Inuit had iron tools from a meteorite, so Anthropologists believed that they were superior to their stone tool counterparts. ${ }^{76}$ By comparing the brain size between the Inuit of Smith Sound with other "samples," Hrdlička also showed that tool use was linked to brain size and intelligence. Despite the discrepancy in brain size, this argument affirmed contemporary perceptions of Euro-American superiority because of their technology. Hrdlička explained away the brain size issue because of "individual conditions." "This value system of ranking based on brain size and the theft of bones were all symptoms of Euro-American Imperialism towards Indigenous groups.

Hrdlička was also involved in the Louisiana Purchase Exhibition (LPE) of 1904. Parezo and Fowler argue that by the 1870 s, the methodology of anthropometry was noted to have problems particularly with the racial evolutionary typologies that obscured cultural differences. ${ }^{78}$ The example of Hrdlička with Qisuk, as well as Hrdlička and William McGee at the LPE, demonstrated that some still considered it a valid form of science despite the methodological issues. McGee was the head of the anthropology department for the LPE and he conferred with Boas, Hrdlička, and others for his anthropology exhibit. Hrdlička was initially going to perform anthropometric experiments during the exposition, but because of funding, Robert Woodworth and Frank Bruner were the scientists at the fair instead. ${ }^{79}$ Although Hrdlička was no longer directly involved, he wrote that he wanted any "individuals [who]... [would] succumb to the climate... These bodies [would] be precious material for both anatomy and anthropology." ${ }^{\prime 00}$ His wish was granted and Hrdlička managed to secure over two hundred bodies of people who died of smallpox, beriberi, and pneumonia for the American Museum of Natural History. ${ }^{81}$

White visitors viewed the laboratory where the anthropometric experiments were underway and were given directions on how to measure themselves. Parezo and Fowler suggested visitors perceived the laboratory as a success because the experiments were a "...foregone conclusions that simply reinforced the celebration of human progress seen through out the fair... Visitors saw difference being scientifically proven..." right before their eyes. ${ }^{82}$ The fact that these experiments were open for visitors to observe gave it a similar role to museum displays. The public's concepts of race were formed and reinforced by visiting the lab. The opportunity to measure each other ensured a favourable memory of the experience beyond what a simple lecture would have done. This makes this public lab an incredibly powerful tool for the perpetuation of Orientalist conceptions. Not only were these ideas reinforced by audience participation and hands-on activities, but they were also in the dangerous, powerful guise of science.

\footnotetext{
75 Ibid., 500.

${ }^{76}$ Harper, My Father's Body, 18.

${ }^{77}$ Hrdli ka, "An Eskimo Brain," 500.

${ }^{78}$ Parezo, Anthropology goes to the Fair, 307.

${ }^{79}$ Ibid., 309-12.

${ }^{80}$ Ibid., 309.

${ }^{81}$ Ibid., 320.

${ }^{82}$ Ibid., 321.
} 
Exploration of Said's theories in application to my research has confirmed some parts of his model. However, other aspects of his theory leave unresolved issues. The hegemonic aspect of his theory is particularly problematic. Said argues that the classification and creation of knowledge of the Other was a way to dominate, yet he does not consider the ways that subordinate group subvert the dominant power for their own purposes. It is possible that Indigenous people could profit from stereotypes created about them, although it is undeniable that such profit would perpetuate stereotypes. Aboriginal agency appears negligible according to the 'othering' process, solely restricted to the role of 'subject.' More research needs to be done into Aboriginal people's subversion of the process in order to respond to this glaring limitation in the theory. Another weakness for consideration, as MacKenzie notes, is that the theory of Orientalism sees everything in a binary opposition; the West is constantly against the East, the Self is constantly pitted against the Other. ${ }^{83}$ Said's model also focuses on the Orient, however I have proven here that his theory is applicable to the Americas, demonstrating the theory has a greater breadth than first envisioned. Last of all, and most importantly, Said only examines works of "high culture." I feel confident in arguing that other facets of culture, particularly popular culture, actually had a greater impact in the creation of knowledge surrounding the Other. Juvenile literature, movies, popular music, Wild West Shows, World's Fairs, pulp fiction, newspapers and museums reached greater numbers than an obscure book on linguistics and would provide excellent material for future study. The greatest weakness of both Orientalism and Culture and Imperialism is Said's lack of consideration of the enormous impact that "lowbrow" culture can have when it reaches millions of people instead of a few thousand. The greatest strength of the theory of Orientalism is that it expresses a Western framework or discourse in understanding the Orient. ${ }^{84}$ Since Said's book was published, people have taken his theory, and like me, have tried to apply it to other situations. In some instances, his theory fits, but in others, it is too polemical. Regardless of the politics behind Said's work, Orientalism created a way of articulating the sense of domination that many formerly and currently colonized people felt, but were never able to put into words. That in itself is an incredible success.

\footnotetext{
${ }^{83}$ John M. Mackenzie, Orientalism: History, Theory and the Arts (Manchester, Manchester University Press, 1995$), 10$.

${ }^{84}$ Ibid., 10.
} 


\section{Bibliography}

Primary Sources

Arctic Region Life Group, Anthropology Exhibit, U.S. National Museum, c. 1915, 2002-10659, Historic Images of the Smithsonian, Smithsonian Archives (SIRIS), Washington D.C.

Ceramic Collection Lithic Collection, n.d., BAE 4523 00836400, National Anthropological Archives, Smithsonian Institution.

Curtis, Edward S. The Papago Girl, 1907. http://hdl.loc.gov/loc.award/ iencurt.cp02009. Accessed April 16, 2010.

------. The V anishing Race, 1904. http://hdl.loc.gov/loc.award/ iencurt.cp01001. Accessed April 16, 2010.

Hrdlička, Aleš. “An Eskimo Brain.” American Anthropologist 3, no. 3 (1901).

-----. Anthropometry. Philadelphia: The Wistar Institute of Anatomy and Biology. 1920.

Letter of John W. Powell from Yarrow, June 1, 1883. Quoted in Abigail Clouse, "The Social History of a National Collection: Anthropology, Repatriation and the Politics of Identity."

Rousseau, Jean-Jacques. Trans. Donald A. Cress. In "Discourse on the Origins and Foundations of Inequality Among Men," in Jean-Jacques Rousseau: The Basic Political Writings. Hackett Publishing Company, 1987.

Von Humboldt, Alexander. Researches concerning the institutions \& monuments of the ancient inhabitants of America. London, 1814. 1:156. http://galenet.galegroup.com/servlet/

Sabin?af $=\mathrm{RN} \& a \mathrm{e}=\mathrm{CY} 105088918 \& \operatorname{srchtp}=\mathrm{a} \& \mathrm{ste}=14$. Accessed 16 April 2010.

Secondary Sources

Berger, John. Ways of Seeing. Toronto: Penguin Books, 2008. First published in Great Britain by the BBC and Penguin Books Ltd., 1972.

Clouse, Abigail. "The Social History of a National Collection: Anthropology, Repatriation and the Politics of Identity." PhD diss., University of Arizona, 2006.

Greenblatt, Stephen. Marvelous Possessions: The Wonder of the New World. Chicago: The University of Chicago Press, 1991.

Gidley, Mick ed., Edward S. Curtis and the North American Indian Project in the Field. Lincoln: University of Nebraska Press, 2003.

Graybill, Florence Curtis and Victor Boesen. Edward Sheriff Curtis: Visions of a Vanishing Race. New York: Thomas Y. Crowell Company, 1976.

Harper, Kenn. Give Me My Father's Body: The Life and Times of Minik the New York Eskimo. New York: Steerforth Press, 2000. First published in Canada in 1986 by Blacklead Press.

Maurer, Even "Presenting the American Indian" in The Changing Presentation of the American Indian. Seattle: University of Washington Press, 2000.

Penny, H. Glenn. Objects of Culture: Ethnology and Ethnographic Museums in Imperial Germany. Chapel Hill: University of North Carolina Press, 2002.

Mackenzie, John M. Museums and Empire: Natural History, Human Cultures, and Colonial Identities. Manchester: Manchester University Press, 2009.

-----. Orientalism: History, Theory and the Arts. Manchester, Manchester University Press, 1995.

Constellations

Volume 2, No. 2 (Winter 2011) 
Parezo, Nancy J. and Don D. Fowler Anthropology goes to the Fair: The 1904 Louisiana Purchase Exposition. Lincoln: University of Nebraska Press, 2007.

Phillips, Ruth B. Trading Identities: The Souvenir in Native American Art from the Northeast 1700-1900. Montreal \& Kingston: McGill-Queen's University Press, 1998.

Popper, Sir Karl. Conjectures and Refutations: The Growth of Scientific Knowledge. New York: Routledge \& Kegan Paul, 1963. Reprinted in 2004, $2^{\text {nd }}$ ed.

Raibmon, Paige. Authentic Indians: Episodes of Encounter from the Late Nineteenth-Century Northwest Coast. Duke University Press: Durham, 2005.

Said, Edward. Culture and Imperialism. Toronto: Vintage Books a division of Random House ltd. 1994. First published in 1993 by Alfred A. Knopf, Inc.

-----. Orientalism (Toronto: Vintage Books a division of Random House ltd, 1994. First published 1978 by Pantheon Books a division of Random House Ltd. 